(G)

\section{OPEN ACCESS}

'Department of Pathology and Laboratory Medicine, American University of Beirut, Beirut, Lebanon

${ }^{2}$ Department of Internal Medicine, American University of Beirut, Beirut, Lebanon ${ }^{3}$ Boston University School of Medicine, Boston,

Massachusetts, USA

\section{Correspondence to}

Dr Ghazi Zaatari, Department of Pathology and Laboratory Medicine, American University of Beirut, P.O. Box 11-0236, Beirut, 110-72020 Lebanon; zaatari@aub.edu.lb

Received 17 September 2014 Revised 23 December 2014 Accepted 15 January 2015
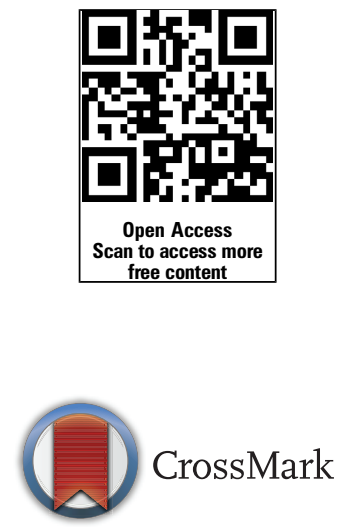

To cite: El-Zaatari ZM Chami HA, Zaatari GS. Tob Control 2015;24:i31-i43.

\title{
Health effects associated with waterpipe smoking
}

\author{
Ziad M El-Zaatari, ${ }^{1}$ Hassan A Chami, ${ }^{2,3}$ Ghazi S Zaatari ${ }^{1}$
}

ABSTRACT

Objective It is widely held that waterpipe smoking (WPS) is not associated with health hazards. However, several studies have documented the uptake of several toxicants and carcinogens during WPS that is strongly associated with harmful health effects. This paper reviews the literature on the health effects of WPS.

Data sources Three databases-PubMed, MEDLINE and EMBASE-were searched until August 2014 for the acute and long-term health effects of WPS using the terms 'waterpipe' and its synonyms (hookah, shisha, goza, narghileh, arghileh and hubble-bubble) in various spellings.

Study selection We included original clinical studies, case reports and systematic reviews and focused on clinical human studies. $\sim 10 \%$ of the identified studies met the selection criteria.

Data extraction Data were abstracted by all three authors and summarised into tables. Abstracted data included study type, results and methodological limitations and were analysed jointly by all three authors. Data synthesis WPS acutely leads to increased heart rate, blood pressure, impaired pulmonary function and carbon monoxide intoxication. Chronic bronchitis, emphysema and coronary artery disease are serious complications of long-term use. Lung, gastric and oesophageal cancer are associated with WPS as well as periodontal disease, obstetrical complications, osteoporosis and mental health problems.

Conclusions Contrary to the widely held misconception, WPS is associated with a variety of adverse short-term and long-term health effects that should reinforce the need for stronger regulation. In addition, this review highlights the limitations of the published work, which is mostly cross-sectional or retrospective. Prospective studies should be undertaken to assess the full spectrum of health effects of WPS, particularly in view of its growing popularity and attractiveness to youth.

\section{BACKGROUND AND INTRODUCTION}

The worldwide prevalence of daily waterpipe smoking (WPS) is estimated to be 100 million $^{1}$ with alarming increasing popularity among the youth. $^{2}$ This global trend is on the rise as per several epidemiological studies and surveys due to the following factors: (1) the introduction of flavoured waterpipe tobacco with its reduced harshness, pleasant flavour and aroma; ${ }^{3} 4$ (2) the misperception that it is 'healthier' than cigarette smoking; ${ }^{3}$ (3) social acceptance and being an essential part of gatherings, and café and restaurant culture $;^{3} 4$ (4) internet, mass and social media; ${ }^{3} 4$ (5) low cost; ${ }^{3}$ (6) lack of waterpipe-specific policy and regulations towards its use; ${ }^{34}$ and (7) immigration of people from Middle Eastern countries to the European Region, the Region of the Americas and the Western Pacific Region. ${ }^{4}$ The perception of safety and harm reduction has been refuted by studies which documented the presence in waterpipe smoke of harmful toxicants and carcinogens 56 that are taken in by smokers and not filtered out by the passing through water.

Contrary to this misconception about the safety of WPS, several studies have demonstrated its adverse health effects on many organs but primarily the cardiovascular and respiratory systems where there is documentation of coronary artery disease (CAD) and obstructive pulmonary disease and increased risk to develop lung cancer. In addition, perinatal effects in smoking mothers, periodontal disease and other health effects have been described in this group of smokers. This paper is a narrative review of the current knowledge on the health effects of WPS and it draws recommendations for the work needed to determine the scope of disease in this group of smokers and highlights the importance of regulatory measures to curb this rapidly growing epidemic.

\section{METHODS}

\section{Eligibility criteria}

For a comprehensive evaluation of published data on the health effects of WPS, a minimally restrictive approach of study inclusion was adopted. All available original clinical studies (cohort, casecontrol and cross-sectional), systematic reviews, case reports and case series were included. Relevant abstracts and full text studies were also included. In vitro and animal studies were included but were not the main focus of this study. Publications that were not eligible were letters and editorials that did not represent original research, or publications that did not assess our main outcomes of interest, that is, effects or outcomes of WPS on human health.

\section{Search strategy}

PubMed, MEDLINE and EMBASE databases were searched from the earliest studies on those databases until 27 August 2014. A medical librarian was consulted and agreed with the search strategy used. The PubMed search was carried out using a strategy employing synonyms of 'waterpipe': waterpipe OR hookah OR shisha OR goza OR narghileh OR arghileh OR hubble-bubble. MEDLINE was searched using previously reported strategies, ${ }^{7}$ which helped identify further studies not found using the former strategy. EMBASE was searched using a modified version of the MEDLINE search, namely searching for terms in titles and abstracts only, including only English language hits for the term "guza", and combining the search terms "water pipe" " or "argil"*" with the term "tobacco". This resulted in a more focused retrieval of studies from EMBASE, since applying the non-modified 
MEDLINE strategy to EMBASE retrieved a very large number of entries irrelevant to the present study.

\section{Selection process}

The studies were selected based on the eligibility criteria outlined above. All three authors agreed on the studies to include in this review.

\section{Data abstraction}

Each included study was reviewed thoroughly and the selected studies were organised and summarised into tables prior to analysis. The abstracted data included acute and long-term health effects and outcomes, populations studied and their demographic characteristics (age, gender, location), study design, methodological flaws such as inclusion of concurrent cigarette smokers or lack of control for other confounders and any other limitations.

\section{Data analysis}

All three authors analysed the data according to their medical experience and knowledge. Strengths as well as flaws associated with the methodology of studies were critiqued. The results of the studies were presented in the context of all other available evidence.

\section{RESULTS}

\section{Effects on the cardiovascular system}

WPS has both acute and long-term effects on the cardiovascular system. WP acutely increases heart rate (HR) and blood pressure (BP) and can lead to decreased baroreflex sensitivity, HR variability and exercise capacity. Chronically, WPS is associated with CAD.

\section{Acute cardiovascular effects}

\section{Heart rate and blood pressure}

The acute cardiovascular effects of WPS were evaluated in mul-

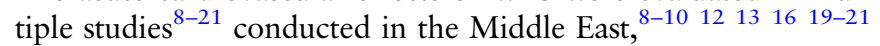
Europe $^{11}$ and the USA, ${ }^{14} 151718$ using an experimental interventional design. Studies that assessed $\mathrm{HR}$ and $\mathrm{BP}^{8-21}$ measured them before and after WPS sessions that lasted 30-60 min after abstaining from WPS and in some cases from caffeine ${ }^{9}{ }^{14}$ or caffeine and alcohol $^{12}$ for varying periods of time. Studies primarily included young healthy participants, either men alone $^{8} 91213$ or men and women, ${ }^{10} 11^{14-21}$ and were conducted in indoor laboratory and café and outdoor environments. Flavoured tobacco (moassal) was most commonly used and the weight ranged from 5-20 g per WP. With few exceptions, significant increases in HR ranging from 4.1 to $16 \mathrm{bpm}$ were observed, ${ }^{8-11}{ }^{14-21}$ as were increases in systolic ${ }^{8-13} 1621$ and diastolic ${ }^{8-12} \quad 14 \quad 16 \quad 20 \quad 21 \quad$ BPs ranging from 6.7 to $15.7 \mathrm{~mm} \mathrm{Hg}$ and from 2.0 to $14 \mathrm{~mm} \mathrm{Hg}$, respectively. The results of these studies are summarised in table 1 . Two studies did not show a change in $\mathrm{BP}^{15}{ }^{18}$ possibly related to lower achieved plasma nicotine levels $(5.6 \mathrm{ng} / \mathrm{mL}$ compared to 19.1 and $60.3 \mathrm{ng} / \mathrm{mL}$ in studies that showed an increase in BP). ${ }^{8} 1618$ The difference in nicotine levels is influenced by multiple factors: the amount of tobacco used $\left(20^{8}\right.$ vs $\left.10 \mathrm{~g}\right){ }^{18}$ the burning temperature and the puffing parameters. ${ }^{22}$ Crossover studies comparing tobacco-based WPS versus WPS nicotine-free herbal or tea products ${ }^{14}{ }^{18}$ implicate nicotine as the mediator of HR increase. This is understandable considering its known sympathetic stimulation effect. ${ }^{23}$ This may be a mechanism shared by WP and cigarettes, as in one crossover study which compared the acute effects of WPS and cigarette smoking. ${ }^{17}$ Smoking one cigarette for 5 min and smoking one WP for 45 min were associated with a similar increase in the nicotine level (10.2 vs $10.5 \mathrm{ng} / \mathrm{mL}$ ) and a slightly smaller increase in HR (10.8 vs $16.8 \mathrm{bpm})$. The nicotine level and HR peaked earlier at 5$10 \mathrm{~min}$ after cigarette smoking but were higher at 30-45 min after WPS. ${ }^{17}$ Another study showed a significantly larger acute increase in HR after 60-90 min of WPS compared with smoking an unspecified number of cigarettes (7.9 vs $0.3 \mathrm{bpm}){ }^{21}$

\section{Other measures of cardiovascular function}

The acute effects of WPS on predictors of cardiovascular disease were also assessed in some of the aforementioned studies (table 1). Baroreflex sensitivity, ${ }^{12} \mathrm{HR}$ variability, ${ }^{14}$ endothelial dysfunction, ${ }^{16}$ exercise capacity ${ }^{13}$ and blood flow ${ }^{20}$ were measured before and after exposure to WPS following an experimental interventional design. The interbeat interval and baroreflex sensitivity dropped significantly from 846 to $709 \mathrm{~ms}$ and from 9.6 to $5.67 \mathrm{~ms} / \mathrm{mm} \mathrm{Hg}$, respectively, in a group of young normotensive men after WPS. ${ }^{12}$ However, the drop in pulse pressure and baroreflex sensitivity did not reach statistical significance. A transient decrease in HR variability, a measure of autonomic cardiac dysregulation and a predictor of CAD and mortality were observed after smoking both tobacco and nicotine-free WP products. ${ }^{14}$ This suggests that smoke constituents other than nicotine impact HR variability. Exercise capacity was evaluated using cardiopulmonary exercise testing in young men after $48 \mathrm{~h}$ of abstinence from WPS and repeated a few days later after a $45 \mathrm{~min}$ WPS session at a café near the testing laboratory. ${ }^{13}$ Both peak exercise capacity as measured by $\mathrm{VO}_{2}$ max and peak $\mathrm{O}_{2}$ pulse (oxygen extracted per heartbeat at peak exercise) decreased from 1.86 to $1.7 \mathrm{~L} / \mathrm{min}$ and from 10.89 to $9.97 \mathrm{~mL} /$ beat, respectively. This drop in peak $\mathrm{O}_{2}$ pulse was attributed to carbon monoxide (CO) induced impairment in vasodilation in the exercising muscle rather than a decrease in the cardiac stroke volume. Postocclusion peripheral forearm arterial and venous blood flow measured by plethysmography decreased significantly and postocclusion arterial vascular resistance increased following a 30 min self-paced WPS session in 53 young WP smokers demonstrating impaired flow-mediated vascular dilation, suggestive of endothelial dysfunction. ${ }^{20}$ However, another study in 47 individuals found no change in endothelial function after WPS as measured by the endopat device. ${ }^{16}$

\section{Long-term cardiovascular effects}

The first publication on the association of WPS with long-term cardiovascular outcomes was an abstract reporting an increased odds of CAD with $\mathrm{OR}=2.2$ (95\% CI 0.9 to 5.4) in individuals who ever smoked WP and $\mathrm{OR}=0.7$ (95\% CI 0.3 to 1.9$)$ in current WP smokers compared with individuals who never smoked. ${ }^{24}$ Since then, more studies have evaluated this association including a cross-sectional study from Iran, ${ }^{25}$ one prospective $\operatorname{study}^{26}$ and one case-control study ${ }^{27}$ from Bangladesh, ${ }^{26} 27$ and three hospital-based cross-sectional studies from Lebanon, ${ }^{28}$ Qatar $^{29}$ and Egypt. ${ }^{30}$ Moreover, one community-based cross-sectional study from Jordan evaluated the association of WPS with hypertension. ${ }^{31}$

In a community-based cross-sectional study of 50045 participants (40-75 years; $42 \%$ males) from Golestan province in Iran, WPS was significantly associated with self-reported prevalent heart disease (ischaemic heart disease or heart failure) after adjusting for demographics and cardiovascular risk factors including physical activity, body mass index (BMI), hypertension and diabetes ( $\mathrm{p}$ for trend=0.04). ${ }^{25}$ Heavy WP users with a history of $>180$ WP-years (WP smoked per day times number 


\begin{tabular}{|c|c|c|c|c|c|c|c|}
\hline Study & Population & $\begin{array}{l}\text { Smoking } \\
\text { abstinence }\end{array}$ & $\begin{array}{l}\text { Smoking session time and } \\
\text { setting }\end{array}$ & $\begin{array}{l}\text { Tobacco type and } \\
\text { amount }\end{array}$ & $\begin{array}{l}\text { HR change } \\
\text { bpm }\end{array}$ & $\begin{array}{l}\text { SBP change } \\
\mathrm{mm} \mathrm{Hg}\end{array}$ & $\begin{array}{l}\text { DBP change } \\
\mathrm{mm} \mathrm{Hg}\end{array}$ \\
\hline Shafogoj $2002^{8}$ & $\begin{array}{l}18 \text { previously healthy, normotensive men, avg. age } 27 \text { years, exclusive } \\
\text { WP smokers }\end{array}$ & $84 \mathrm{~h}$ & $\begin{array}{l}45 \text { min in a well-ventilated } \\
\text { laboratory }\end{array}$ & $20 \mathrm{~g}$ moassal & +16 & +6.7 & +4.4 \\
\hline Shaikh $2008^{9}$ & 202 men, mean age 33.2 years, cigarette smokers excluded & $20 \mathrm{~min}^{*}$ & $\begin{array}{l}30-45 \text { min, in a café } \\
\text { environnement }\end{array}$ & unspecified & +6.3 & +15.7 & +2.0 \\
\hline Hakim $2011^{10}$ & $\begin{array}{l}30 \text { men and } 15 \text { women, mean age } 32.3( \pm 23.4) \text { years. Included } 8 \\
\text { cigarette smokers }\end{array}$ & $24 \mathrm{~h}$ & $\begin{array}{l}30 \text { min in an outdoor } \\
\text { environment }\end{array}$ & $10 \mathrm{~g}$ moassal & +15.2 & +12.5 & +8.2 \\
\hline Kadhum $2014^{11}$ & $\begin{array}{l}49 \text { men and } 12 \text { women, free of cardiorespiratory disease, ages } 18- \\
25 \text { years, cigarette or other tobacco users excluded }\end{array}$ & $\begin{array}{l}\text { Yes, unspecified } \\
\text { duration }\end{array}$ & $45-90$ min in 6 WP cafes & unspecified & +14 & +15 & +10 \\
\hline Al-Kubati $2006^{12}$ & 20 normotensive men, avg. age $27( \pm 6)$ years & $12 \mathrm{ht}$ & $45 \mathrm{~min}$ in a laboratory & $5 \mathrm{~g}$ moassal & NE & +13 & +14 \\
\hline Hawari $2013^{13}$ & 24 healthy men, average age 20.4 years & $48 \mathrm{~h}$ & $45 \mathrm{~min}$ at a café & unspecified & +2.4 (NS) & +10.3 & NS \\
\hline Cobb 2012 14 & $\begin{array}{l}16 \text { men and } 16 \text { women, healthy, age } 18-50 \text { years, regular cigarette } \\
\text { users ( }>5 \text { per day) excluded }\end{array}$ & $12 \mathrm{~h}^{*}$ & $45 \mathrm{~min}$ in a laboratory & $\begin{array}{l}10 \mathrm{~g} \text { flavoured } \\
\text { tobacco }\end{array}$ & +4.1 & +5 (NS) & +6.3 \\
\hline Shishani $2014^{15}$ & 22 adults, avg. age $24( \pm 3)$ years, exclusive WP smokers & $24 \mathrm{~h}$ & $45-60$ in an outdoor laboratory & unspecified & +8 & NS & NS \\
\hline Bentur 2014 & 33 men and 14 women, healthy, average age $24.9( \pm 6.2)$ years & $24 \mathrm{~h}$ & $30 \mathrm{~min}$ in an indoor environment & $10 \mathrm{~g}$ moassal & +15.5 & +8 & +4 \\
\hline Eissenberg $2009^{17}$ & $\begin{array}{l}21 \text { men, } 10 \text { women, healthy, avg. age } 21.4( \pm 2.3) \text { years, both WP and } \\
\text { cigarette smokers }\end{array}$ & $12 \mathrm{~h}$ & $\begin{array}{l}45 \text { min in a laboratory } \\
\text { environment }\end{array}$ & $\begin{array}{l}15 \mathrm{~g} \text { flavoured } \\
\text { tobacco }\end{array}$ & +6.3 & $\mathrm{NE}$ & $\mathrm{NE}$ \\
\hline Blank $2011^{18}$ & 29 men, 8 women, healthy, avg. age 20 years & overnight & $45 \mathrm{~min}$ in a ventilated laboratory & $\begin{array}{l}10 \mathrm{~g} \text { flavoured } \\
\text { tobacco }\end{array}$ & +8.6 & +1.7 (NS) & NS \\
\hline Al-Osaimi $2012^{19}$ & 220 WP smokers & unspecified & $30 \mathrm{~min}$ & unspecified & +15 & NE & NE \\
\hline Alomari $2014^{20}$ & 34 men, 19 women, avg age $22.7( \pm 4.8)$ years, range $18-35$ years & unspecified & $\begin{array}{l}30 \text { min in a well-ventilated, } \\
\text { air-conditioned room }\end{array}$ & $\begin{array}{l}10 \mathrm{~g} \text { flavoured } \\
\text { tobacco }\end{array}$ & +5.2 & +1.7 (NS) & +2.4 \\
\hline Layoun $2014^{21}$ & 87 men, 45 women, avg age $33.4( \pm 13.29)$ years, exclusive WP smokers & unspecified & $\begin{array}{l}45 \mathrm{~min} \text { at restaurants in Beirut } \\
\text { and } \mathrm{Mt} \text { Lebanon }\end{array}$ & $\begin{array}{l}20 \mathrm{~g} \text { moassal } \\
\text { tobacco }\end{array}$ & $+7.09 \ddagger$ & $+0.7 \neq$ & $+2.6 \neq$ \\
\hline \multicolumn{8}{|c|}{$\begin{array}{l}\text { *Also abstained from caffeine. } \\
\text { tAlso abstained from caffeine and alcohol. } \\
\text { †Statistical significance unspecified.DBP, diastolic blood pressure; HR, heart rate; NE, not evaluated; NS, not statistically significant; SBP, systolic blood pressure. }\end{array}$} \\
\hline
\end{tabular}


of smoking years) had 3.75 times the odds (95\% CI 1.5 to 9.2 $\mathrm{N}=25$ ) of heart disease compared to never users. Moderate to heavy WP users with $>50$ WP-years had 1.83 times the odds (95\% CI 1.1 to $3.1 \mathrm{~N}=120$ ) of heart disease compared to low users and never users ( $<50$ WP-years). The limitations of this study are its cross-sectional design with the potential for recall bias, and the low prevalence of WPS with primarily light use, which could have biased against finding a significant association with heart disease in the non-heavy WP users. Indeed, the odds of heart disease in an ever WP user $(\geq 1 \mathrm{WP} /$ week for 6 -month) was 1.09 (95\% CI 0.8 to $1.5 \mathrm{~N}=525)$ compared to never users. Furthermore, important CAD risk factors such as hyperlipidaemia and family history of CAD were not accounted for. In the large prospective community-based Health Effects of Arsenic Longitudinal Study (HEALS) that included 20033 individuals in Araihazar, Bangladesh, women who ever smoked WP had 2.81 (95\% CI 1.78 to 4.43 ) times the risk of death from any cause compared to non-WP smokers. ${ }^{26}$ In men, only heavy smokers who reported smoking WP $>5$ times per day had increased risk of death from any cause (hazard ratio $=1.35$ 95\% CI 1.05 to 1.76 ) and from ischaemic heart disease (hazard ratio $=1.96$, 95\% CI 1.05 to 3.63 ) compared to non-WP smokers. Although analyses were adjusted for age and BMI, 99\% of WP smokers were cigarette or beedi smokers, making it impossible to isolate the effect of WPS. In another study, WPS was not associated with stroke-related death risk. ${ }^{27}$

Three hospital-based studies assessed the association of WPS and heart disease. The first evaluated the association with angiographically defined CAD in 1210 patients from four hospitals in Lebanon. ${ }^{28}$ Patients with $>40$ WP-years smoking had three time the odds of severe stenosis $(>70 \%)$ compared to non-smokers $(\mathrm{OR}=2.9595 \%$ CI 1.04 to 8.33$)$, adjusting for demographics and CAD risk factors-cigarette smoking, alcohol consumption, physical activity, diabetes, hypertension, hyperlipidaemia and family history of CAD. Furthermore, WPS was associated with the extent of CAD measured by the Duke CAD prognostic index. Although cigarette smoking history was adjusted for, there was a potential residual confounding effect due to the significant concurrent (29\%) or previous cigarette smokers (12.2\%). To minimise recall bias inherent to the cross-sectional design, participants were interviewed prior to their knowledge of CAD results. The second study investigated the outcome of acute coronary syndrome in 7930 hospitalised patients of whom 306 (3.9\%) were WP smokers. ${ }^{29}$ Although WP smokers were older than cigarette smokers, the age-adjusted in hospital mortality was significantly higher in WP smokers $(\mathrm{OR}=1.8)$. Furthermore, WP smokers experienced significantly higher rates of recurrent ischaemia (26.9\%) compared to cigarette smokers (14.1\%). Finally, a third study, which included 287 patients referred for coronary revascularisation at a single centre in Egypt, reported that the Duke CAD prognostic index was highest among WP smokers (6.96, SD3.28) and mixed smokers (6.92, SD3.1), followed by cigarette smokers (6.14, SD3.02) and non-smokers (5.41, SD3.06). ${ }^{30}$ Although CAD risk factors were more common among WP smokers and diabetes was more common in non-smokers, analyses adjusting for these factors were not reported, thus limiting this analysis. Furthermore, none of the females included in this study reported WP or cigarette smoking.

A recent study found a weak association between exclusive long-term WPS and increased BP and HR $(p=0.05, p=0.01$, respectively). ${ }^{21}$ Another community-based cross-sectional study found no association between exclusive WPS and hypertension in 14310 healthy young adults (mean age $31.4 \pm 14.2$ years, $48 \%$ females), primarily university students. ${ }^{31}$ Compared to nonsmokers, BP and HR were significantly higher in participants who smoked cigarettes alone or cigarettes and WP concurrently, but not in pure WP smokers. However, the vast majority of WP smokers were light users who reported smoking one to two times per week. The study was further limited by a lack of adjustment for important predictors of hypertension and duration of smoking. Thus, although $\mathrm{BP}$ and $\mathrm{HR}$ are proven to acutely increase after WPS, such evidence for long-term increase is weak.

\section{Mechanisms for WP-induced cardiovascular disease}

Multiple mechanisms can mediate the association of WPS with cardiovascular disease. Flow-mediated dilation was lowest in otherwise healthy WP smokers followed by age-matched and sex-matched cigarette smokers and non-smokers, suggesting a higher degree of endothelial dysfunction. ${ }^{32}$ Reduced HR variability (referred to above) and increased oxidative stress, the latter persisting after 2 weeks of sustained smoking, ${ }^{33}$ are other possible mechanisms. Finally, enhanced thrombosis and oxidation of cholesterol are other potential mechanisms that were implicated in cigarette smoking ${ }^{34}$ but have not been evaluated in WPS.

\section{Effects on the respiratory system}

Similar to the cardiovascular system, WPS has acute and longterm effects on the respiratory system. The former are reflected in increased respiratory rate $(\mathrm{RR})$ and $\mathrm{CO}$, in addition to changes in pulmonary function $(\mathrm{PF})$ and exercise capacity. Chronically, CO levels may be elevated and PF can become permanently altered, leading to chronic obstructive pulmonary disease (COPD). Chronic bronchitis, emphysema and exacerbation of asthma are other pulmonary manifestations of WPS.

\section{Acute respiratory effects}

A number of experimental interventional studies, conducted from UAE, ${ }^{9}$ Israel, ${ }^{10}{ }^{16}$ Jordan $^{13}$ and Lebanon, ${ }^{21}$ in café,,${ }^{13}$ restaurant, ${ }^{21}$ other indoor ${ }^{16}$ or outdoor environments, ${ }^{10}$ measured the acute effect of WPS on the respiratory system (table 2). Four showed a significant increase in RR that varied between 2 and 3.5 breaths per minute after 30-45 min of WPS. ${ }^{910} 1316$ Four studies measured the acute effect on PF. ${ }^{10} 131621$ Forced expiratory flow (FEF25-75) ${ }^{10} 13$ and peak expiratory flow rate ${ }^{10} 16$ decreased significantly post-WPS, suggesting small airway dysfunction. However, there was no change in the main spirometric measurements: forced expiratory volume in $1 \mathrm{~s}\left(\mathrm{FEV}_{1}\right)$, forced vital capacity (FVC) and $\mathrm{FEV}_{1} / \mathrm{FVC}^{10} 131621$ or in gas exchange at rest as measured by diffusing capacity for carbon monxide (DLCO). ${ }^{13}$ Perceived dyspnoea as measured by the Borg scale increased at mid and peak exercise after WPS; however, using formal cardiopulmonary exercise testing, maximal ventilatory capacity, breathing reserve and oxygen saturation at peak exercise did not change after WPS. ${ }^{13}$ An average significant decrease in oxygen saturation by $0.39 \%$ after a 30 min WPS session was reported in another study. ${ }^{19}$ Overall, participants were young, healthy and smoked at their own pace. Smoking abstinence ranged from $20 \mathrm{~min}^{9}$ to $48 \mathrm{~h}^{13}$ before experimentation, with one study not specifying this type of control. ${ }^{21}$ Two studies included both men and women and the participants smoked a controlled amount of the same tobacco. ${ }^{10} 16$ One study included a passive smoking group with no significant changes in $\mathrm{PF}^{16}$

\section{CO Toxicity}

WPS acutely leads to a marked CO inhalation and increased carboxyhaemoglobin $(\mathrm{COHb})$ or exhaled $\mathrm{CO}$ when compared 


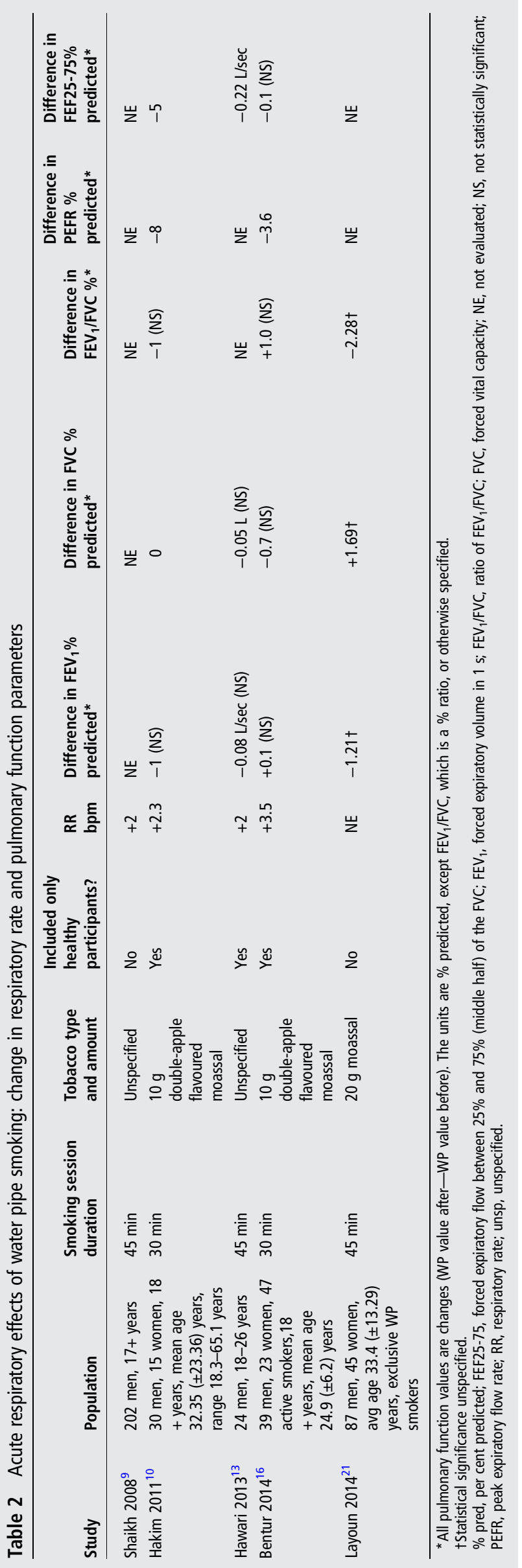

to cigarette smokers ${ }^{17}{ }^{35-37}$ and non-smokers. ${ }^{36-38}$ An acute increase in $\mathrm{CO}$ levels (exhaled $\mathrm{CO}$ or $\mathrm{COHb}$ ) is demonstrated in smokers following a timed WPS session ${ }^{8} 10 \quad 11$ 13-18 $39-42$ after exiting WP cafés ${ }^{43}$ or compared to non-WP cafés, ${ }^{44}$ and among passive smokers. ${ }^{16} 4145 \mathrm{COHb}$ compromises the transportation of oxygen to various organs, including the brain, and can cause dizziness, headache, syncope and nausea. Acute CO poisoning after WPS is widely reported in the literature as case reports ${ }^{46-56}$ and manifests with markedly elevated blood $\mathrm{COHb}$ levels and various symptoms that resolve after therapy. The increase in exhaled $\mathrm{CO}$ levels is probably tobacco-independent and related to charcoal as CO levels after tobacco-free WPS were similar to ${ }^{14} 18$ or larger than ${ }^{15}$ tobacco-based WPS.

Long-term respiratory effects

Carbon monoxide

WPS may lead to a long-term increase in $\mathrm{COHb}$ to levels greater than those in cigarette smokers ${ }^{57}$ and to polycythaemia. ${ }^{58} 59$ In fact, WPS was a predictor of increased exhaled CO levels in Lebanese residents aged 40 and above. ${ }^{60}$

\section{Pulmonary function}

Several studies assessed PF in long-term WP smokers compared to non-smokers (table 3). ${ }^{21}{ }^{61-71}$ These cross-sectional studies were mostly community-based, ${ }^{61-66}{ }^{68-71}$ with one hospitalbased study, ${ }^{67}$ and were conducted in Iran, ${ }^{61}{ }^{71}$ Tunisia, ${ }^{62} 63$ Kuwait, ${ }^{64}$ Turkey, $^{65}{ }^{66}$ Syria, ${ }^{67}{ }^{68}$ China $^{69}$ and Saudi Arabia. ${ }^{71}$ $\mathrm{PF}$ was impaired as measured by $\mathrm{FEV}_{1},{ }_{1}{ }_{1} 63$ 69-71 $\mathrm{FVC},{ }^{21} 617071 \mathrm{FEV}_{1} / \mathrm{FVC}^{66} 6970$ or FEF25-75, ${ }^{616371}$ while two studies did not demonstrate impairment of these parameters ${ }^{64}{ }^{67}$ Air trapping was reported in WP smokers in one study ${ }^{62}$ although other PF parameters such as total lung capacity $^{62}{ }^{63}$ and DLCO $^{65}$ were not altered. While the results of these studies are inconsistent, a meta-analysis of six crosssectional studies found that $\mathrm{FEV}_{1}$ and $\mathrm{FEV}_{1} / \mathrm{FVC}$ were significantly reduced with a trend towards lower FVC in an obstructive pattern. ${ }^{72}$ Furthermore, long-term WP smokers had a shorter 6 min-walk-test distance compared to healthy non-smokers. ${ }^{73}$

Studies that evaluated the associations between the total number of WPs, ${ }^{61} 71$ total weight of tobacco smoked $^{62}$ or WP-years ${ }^{66}$ and $\mathrm{PF}$ parameters reported a significant moderate negative correlation with $\mathrm{FEV}_{1} \mathrm{r} \sim-0.35 .{ }^{61} 626671$ Other negative correlates of the amount of WP smoked include FVC r -0.39, ${ }^{61}{ }^{71}$ FEF25-75, ${ }^{61} 6271$ peak expiratory flow ${ }^{61} 6271$ and $\mathrm{FEV}_{1} / \mathrm{FVC}^{62} \mathrm{~A}$ significant positive correlation between the amount of WPS and functional residual capacity and residual volume was also reported. ${ }^{62}$

\section{COPD, chronic bronchitis, emphysema, asthma and others}

While studies on PF parameters provide preliminary evidence that WPS causes respiratory disease, a few studies have shown an association with frank clinical syndromes. The GOLD guidelines define COPD by the presence of FEV1/FVC $<70 \%$ on spirometry. ${ }^{74}$ Four cross-sectional community-based studies ${ }^{69}{ }^{75-77}$ and one hospital-based study ${ }^{67}$ evaluated the association of WPS with COPD. These studies were conducted in Syria, ${ }^{67}$ Lebanon, ${ }^{75}$ the UAE, ${ }^{77}$ China $^{69}$ and several Middle Eastern and North African Countries. $^{76}$ Two studies, using the GOLD spirometry-based definition of COPD, found an association between COPD and smoking the traditional ${ }^{75}(\mathrm{OR}=2.53,95 \%$ CI 1.83 to 3.50$)$ or Chinese WP (OR=10.61, 95\% CI 6.89 to 16.34). ${ }^{69}$ (The Chinese WP is similar to the regular traditional Middle Eastern WP, but the tobacco is lit directly without charcoal.) Both analyses adjusted for 
Table 3 Long-term effect of waterpipe smoking on pulmonary function

\begin{tabular}{|c|c|c|c|c|c|c|c|c|c|}
\hline Study & Population & WP quantity & Tobacco type & $\begin{array}{l}\text { Included only } \\
\text { healthy participants? }\end{array}$ & Comparison & Diff in $\mathrm{FEV}_{1} \%$ pred* & Diff in FVC \%pred* & Diff in $\mathrm{FEV}_{1} / \mathrm{FVC} \%$ * & $\begin{array}{l}\text { Diff in FEF25-75\% } \\
\text { pred }^{*}\end{array}$ \\
\hline Boskabady $2012^{61}$ & $\begin{array}{l}371 \text { men, } 301 \text { women, } \\
\text { average ages in } 30 \mathrm{~s} \\
\text { and } 40 \mathrm{~s}\end{array}$ & $\begin{array}{l}\text { Average (Avg) } \\
1.17( \pm 0.53) \text { WP } \\
\text { smoked per week }\end{array}$ & Unspecified & Yes & $\begin{array}{l}\text { WP vs } \\
\text { non-smokers } \\
\text { WP vs cigarette } \\
\text { (normal inhalation) }\end{array}$ & $\begin{array}{l}-14.6 \\
-3.83 \text { (NS) }\end{array}$ & $\begin{array}{l}-21.9 \\
-7.03\end{array}$ & $\mathrm{NE}$ & $\begin{array}{l}-13.8 \\
-13.0\end{array}$ \\
\hline Ben Saad $2013^{63}$ & $\begin{array}{l}142 \text { men age } \\
35-60 \text { years }\end{array}$ & $\begin{array}{l}\text { Avg } 36( \pm 22) \\
\text { WP-years }\end{array}$ & $\begin{array}{l}\text { Tabamel } \\
\text { (sweetened } \\
\text { tobacco) }\end{array}$ & Yes & WP vs cigarette & +24.0 & +14.0 & +13.0 & NE \\
\hline Ben Saad $2011^{62}$ & $\begin{array}{l}110 \text { men, age } \\
20-60 \text { years }\end{array}$ & $\begin{array}{l}\text { Median } 14 \\
\text { WP-years } 14\end{array}$ & Unspecified & Yes & $\begin{array}{l}\text { WP vs reference } \\
\text { values }\end{array}$ & $\dagger$ & $t$ & $t$ & $\dagger$ \\
\hline Mutairi $2006^{64}$ & $\begin{array}{l}139 \text { men, } 13 \text { women, } \\
\text { age } 24-65 \text { years }\end{array}$ & unspecified & Moassal, & Yes & $\begin{array}{l}\text { WP vs cigarette } \\
\text { WP vs } \\
\text { non-smokers }\end{array}$ & $\begin{array}{l}-1.1 \text { (NS) } \\
-12.2 \text { (NS) }\end{array}$ & $\begin{array}{l}\mathrm{NE} \\
\mathrm{NE}\end{array}$ & $\begin{array}{l}+0.5 \neq(\mathrm{NS}) \\
-2.5 \neq(\mathrm{NS})\end{array}$ & $\begin{array}{l}\mathrm{NE} \\
\mathrm{NE}\end{array}$ \\
\hline Aydin $2004^{65}$ & $\begin{array}{l}25 \text { persons average age } \\
49.2( \pm 12.2) \text { years }\end{array}$ & $\begin{array}{l}\text { Avg } 23.7( \pm 8.3) \\
\text { years smoking 1- } \\
2 \text { times/day }\end{array}$ & Unspecified & Yes & $\begin{array}{l}\text { WP vs passive } \\
\text { cigarette smokers }\end{array}$ & -2.5 (NS) & +0.9 (NS) & $-5.6 \ddagger$ & -7.2 (NS) \\
\hline Kiter $2000^{66}$ & $\begin{array}{l}397 \text { men, age } \\
18-85 \text { years }\end{array}$ & $\begin{array}{l}\text { Average } 37( \pm 42) \\
\text { Jurak-years }\end{array}$ & $\begin{array}{l}\text { Jurak } \\
\text { (tobacco-fruit } \\
\text { mixture) }\end{array}$ & No & $\begin{array}{l}\text { WP vs } \\
\text { non-smokers } \\
\text { WP vs cigarette }\end{array}$ & $\begin{array}{l}-6.5 \\
+3.01\end{array}$ & $\begin{array}{l}-5.86 \text { (NS) } \\
-0.5 \text { (NS) }\end{array}$ & $\begin{array}{l}-3.02 \ddagger \\
+4.49 \ddagger\end{array}$ & $\begin{array}{l}-8.63 \\
+5.08\end{array}$ \\
\hline Mohammad $2013^{67}$ & $\begin{array}{l}788 \text { women, age } 44 \\
\text { + years }\end{array}$ & Unspecified & Unspecified & No & $\begin{array}{l}\text { WP vs cigarette } \\
\text { WP vs } \\
\text { non-smokers }\end{array}$ & +5.3 (NS) & $\mathrm{NE}$ & +0.1 (NS) & $\mathrm{NE}$ \\
\hline She $2014^{69}$ & $\begin{array}{l}1238, \text { mostly men, age } \\
40+\text { years }\end{array}$ & $\begin{array}{l}\text { Average } 28 \\
( \pm 11.2) \text { years of } \\
17.9( \pm 8.9) \mathrm{g} \\
\text { tobacco/day }\end{array}$ & $\begin{array}{l}\text { Chinese WP } \\
\text { tobacco }\end{array}$ & Yes & $\begin{array}{l}\text { WP vs } \\
\text { non-smokers } \\
\text { WP vs cigarette } \\
\text { WP passive vs } \\
\text { never-passive } \\
\text { WP passive vs } \\
\text { cigarette-passive }\end{array}$ & $\begin{array}{l}-9.4 \\
-4.0 \\
-9.0 \\
-6.9\end{array}$ & $\begin{array}{r}+6.1 \\
+7.1 \\
-6.6 \\
-5.5\end{array}$ & $\begin{array}{l}-12.1 \\
-8.0 \\
-4.5 \\
-3.0\end{array}$ & $\begin{array}{l}\text { NE } \\
\text { NE } \\
\text { NE } \\
\text { NE }\end{array}$ \\
\hline Al-Fayez $1988^{70}$ & $\begin{array}{l}441 \text { men, } 154 \text { women } \\
\text { smokers, } 878 \text { total } \\
\text { participants, men } \\
20-59 \text { years, women } \\
17-59 \text { years }\end{array}$ & Not reported & $\begin{array}{l}\text { Jurak } \\
\text { (tobacco-fruit } \\
\text { mixture) }\end{array}$ & Yes & $\begin{array}{l}\text { WP smokers vs } \\
\text { non-smokers } \\
\text { Males } \\
\text { Females }\end{array}$ & $\begin{array}{l}-0.54 \mathrm{~L} \\
-0.41 \mathrm{~L}\end{array}$ & $\begin{array}{l}-0.43 \mathrm{~L} \\
-0.19 \mathrm{~L}\end{array}$ & $\begin{array}{l}-4.6 \\
-11.42\end{array}$ & $\begin{array}{l}\mathrm{NE} \\
\mathrm{NE}\end{array}$ \\
\hline Boskabady $2014^{71}$ & $\S$ & $\S$ & $\S$ & $\S$ & $\S$ & $\S$ & $\S$ & $\S$ & $\S$ \\
\hline Layoun $2014^{21}$ & $\begin{array}{l}87 \text { men, } 45 \text { women, avg } \\
\text { age } 33.4( \pm 13.29) \text { years, } \\
\text { exclusive WP smokers }\end{array}$ & $\begin{array}{l}\text { Avg } 11.12 \\
( \pm 17.27) \text { WPI } \\
\text { week }\end{array}$ & Moassal & No & $\begin{array}{l}\text { WP vs } \\
\text { non-smokers } \\
\text { WP vs cigarette }\end{array}$ & $\begin{array}{l}-4.4 \text { (NS) } \\
+1.63 \text { (NS) }\end{array}$ & $\begin{array}{l}-9.1 \\
-2.28 \text { (NS) }\end{array}$ & $\begin{array}{l}+5.56 \\
+4.28\end{array}$ & $\begin{array}{l}\mathrm{NE} \\
\mathrm{NE}\end{array}$ \\
\hline
\end{tabular}

*All pulmonary function values are differences (WP value-comparison group value). The units are $\%$ predicted, except $\mathrm{FEV}_{1} / \mathrm{FVC}$, which is a $\%$ ratio, or otherwise specified.

TFEV 1 and FEF25-75 decreased compared to reference values; no comparison group was included. FVC and FEV $1 / F V C$ were non-significant in this comparison.

$\ddagger$ Per cent predicted value.
\$Same as 2012 data.

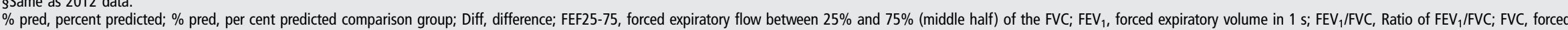

vital capacity; NE, not evaluated; NS, no significant difference with comparison group; unsp, unspecified; unsp, unspecified. 
possible confounders such as age and cigarette smoking. The association of WP with COPD was also ascertained using an epidemiological questionnaire-based definition $(\mathrm{p}<0.026$ for having COPD symptoms compared to non-smokers). ${ }^{76}$ In contrast, two studies found no association between WP and COPD, but were methodologically limited. ${ }^{67} 77$ One included women only and did not account for the total quantity of WP smoked ${ }^{67}$ thus, women may have been exposed to less WP smoke than participants in other studies, accounting for the lack of association. In addition, this study included women as young as 20 years and did not pilot test its survey, report on randomisation methods or calculate the sample size. ${ }^{67}$ The second study had a low COPD prevalence and inadequate power. ${ }^{77}$

WPS was also associated with chronic bronchitis and emphysema in cross-sectional studies from Lebanon, ${ }^{45} 78$ Iran, ${ }^{61}$ China $^{69}$ and a combination of Middle Eastern and North African countries. ${ }^{76}$ Overall, the studies were robust in design including randomisation, ${ }^{69} 7678$ good survey designs, ${ }^{61} 79$ adequate power $^{617879}$ and controlling for cigarette smoking ${ }^{61} 6976$ and other confounders. ${ }^{78} 79$ The associations between WPS and chronic bronchitis, using the standard definition (chronic cough with sputum production for 3 consecutive months for 2 years), were: adjusted $\mathrm{OR}=1.42,95 \% \mathrm{CI} 1.12$ to $1.8,{ }^{76}$ adjusted $\mathrm{OR}=3.4$ for $>6 \mathrm{WP}$ smoked per week, ${ }^{78}$ and adjusted $\mathrm{OR}=5.65$ for $>20$ WP-years. ${ }^{79}$ Another study found that symptoms of chronic bronchitis, using the standard definition, were more severe in WPS compared to non-smokers $(p=0.003)$. An association between Chinese WPS and chronic bronchitis and emphysema was also reported; however, in contrast to other studies, the standard definition of chronic bronchitis was not used. ${ }^{69}$ Another study that conducted a multivariable analysis found that chronic cough but not chronic sputum production was more prevalent in individuals with occupational exposure to WP smoke. ${ }^{45}$

The association of physician-diagnosed asthma in Lebanon with WPS was of borderline significance after adjusting for cigarette smoking and other variables. ${ }^{78}$ Furthermore, data were collected by phone interviews, making the diagnosis unreliable. Another study from India reported an association between asthma and WPS but did not differentiate between WPS and other forms of smoking. ${ }^{80}$ Therefore, an association between WPS and asthma remains inconclusive.

\section{Mechanisms of WP-induced respiratory disease}

Possible mechanisms of respiratory diseases in WPS were explored in in vitro and in vivo studies. WPS resulted in increased airway resistance, lung inflammation, oxidative stress ${ }^{81}$ and catalase activity in animal lungs. ${ }^{82}$ Rats exposed to WPS over several weeks had higher red blood cell counts and haematocrit, supporting an association with chronic polycythaemia. ${ }^{83}$ WP smoke exposure led to decreased neutrophils, lymphocytes, eosinophils and interferon- $\gamma$ and higher nitric oxide in the bronchioalveolar lavage fluid of asthmatic mice, similar to cigarette smoke exposure, and thus may contribute to asthma exacerbations by suppressing helper T1 cells. $^{84}$ In humans, levels of inflammatory cytokines were decreased in the exhaled breath of WP smokers, ${ }^{16}$ while the bronchioalveolar lavage fluid of WPS with COPD had increased metalloproteinase two and nine gene expression similar to that of cigarette smokers with COPD. ${ }^{85}$ These findings need further investigation to understand their implication to human disease.

\section{Association of WPS with cancer}

WP smoke has in vitro been associated with genotoxicity and cellular changes that may lead to cancer. WP smokers had greater chromosomal aberrations by karyotype testing, ${ }^{86}$ increased sister chromatid exchanges in lymphocytes ${ }^{87}$ and increased micronuclei in buccal mucosa cells. ${ }^{88}$ A second study also found increased sister chromatid exchanges and chromosomal aberrations in addition to mitotic index and satellite associations in somatic chromosomes of WP smokers. ${ }^{89}$ Exposure of human alveolar cells to WP smoke resulted in reduced cell proliferation, cell cycle arrest and increased doubling time. ${ }^{86}$ Increased nuclear size, nuclear/cytoplasmic ratio and Feret ratio and decreased cytoplasm size were found in the oral mucosa cells of WP smokers. ${ }^{90}$

Several studies evaluated the association of WPS with cancer (table 4). In the HEALS project, current male WP smokers had 2.5 times the risk of cancer death (95\% CI 1.08 to 5.82) compared to non-WP smokers. ${ }^{26}$ As previously noted, 99\% of WP smokers were cigarette or beedi smokers, making it impossible to isolate the effect of WPS. Furthermore, the small number of cancer related deaths precluded assessment of cancer mortality in women and in different subtypes of cancer.

\section{Lung cancer}

Several methodologically limited case-control studies from Lebanon, ${ }^{91}$ India ${ }^{92} 93$ and China ${ }^{94} 95$ and one Chinese cohort study $^{96}$ support an association between WPS and lung cancer. A sixfold greater risk of lung cancer was noted among former Lebanese WP smokers ${ }^{91}$ and in a group of current Indian WP smokers. ${ }^{92}$ However, the association was not adjusted for confounders in the latter study and became non-significant after adjustment for confounders in the former study. In another study that adjusted for age and education, the odds of lung cancer in Indian male heavy WP smokers of $>45$ years were 4.44. ${ }^{93}$ Three studies also found an association between WPS and lung cancer in China ${ }^{94-96}$ and a meta-analysis reported a pooled OR of 2.12 for lung cancer in WPS. ${ }^{7}$ However, the Chinese studies did not account for cigarette smoking ${ }^{92}$ or Chinese long-stem pipe smoking ${ }^{95} 96$ or control for other possible confounders. ${ }^{94}$ Thus, while cigarette smoking is a wellestablished risk factor for lung cancer, ${ }^{97}$ the evidence linking WPS and lung cancer is limited and more robust studies are needed to elucidate this relationship.

\section{Oesophageal, gastric, bladder and other cancers}

Three case-control studies from India ${ }^{98} 99$ and $\operatorname{Iran}^{100}$ and a meta-analysis support an association between WPS and oesophageal cancer. One study showed twice the risk $(\mathrm{OR}=1.85,95 \%$ CI 1.41 to 2.44) of oesophageal squamous cell carcinoma in WPS and a higher risk of cancer with greater intensity, duration and cumulative WPS. ${ }^{98}$ Another study found very high odds of oesophageal cancer $(\mathrm{OR}=21.4,95 \% \mathrm{CI} 11.6$ to 39.5$)$ among WP smokers; however, data on concomitant use of cigarettes or other forms of tobacco were lacking. ${ }^{99}$ One study ${ }^{100}$ that controlled for cigarettes and other confounders did not demonstrate significant association between exclusive WPS and oesophageal squamous cell cancer $(\mathrm{OR}=1.66,95 \% \mathrm{CI} 0.65$ to 4.22$){ }^{100}$

Two of four studies support an association of WPS with gastric cancer. A large prospective cohort study in Iran reported three times greater risk of gastric cancer $(\mathrm{OR}=3.4,95 \% \mathrm{CI} 1.7$ to 7.1) in WPS after adjusting for cigarette smoking and other risk factors. ${ }^{101}$ A significant association between WPS and gastric cancer was also observed in a case-control study available in abstract form, also from Iran. ${ }^{102}$ One study reported a nonsignificant association with gastric cancer; however, the number of WP smokers included in the study was too small to measure the effect with confidence. ${ }^{103}$ Another study reported associations with gastric and oesophageal cancers, but again the 
Table 4 Studies on associations of waterpipe smoking (WPS) and cancer

\begin{tabular}{|c|c|c|c|c|c|c|c|}
\hline Study & Cancer type & Population & Study type & $\begin{array}{l}\text { Controlled for } \\
\text { cigarette } \\
\text { smoking? }\end{array}$ & $\begin{array}{l}\text { Adjusted for other } \\
\text { confounders? }\end{array}$ & OR $(95 \% \mathrm{Cl})$ & Comments \\
\hline Wu $2013^{26}$ & All cancer death & $\begin{array}{l}20033 \text { Bangladeshi } \\
\text { individuals }\end{array}$ & $\begin{array}{l}\text { Prospective } \\
\text { community-based }\end{array}$ & No & Yes & Adjusted=2.5 (1.08 to 5.82 ) & \\
\hline Auon $2013^{91}$ & Lung & $\begin{array}{l}150 \text { Lebanese } \\
\text { individuals }\end{array}$ & Case-control & Yes & Yes & $6.0(1.78$ to 20.26$)$ & Non-significant OR after adjustment for confounders \\
\hline Koul $2011^{92}$ & Lung & $\begin{array}{l}751 \text { Indian } \\
\text { individuals }\end{array}$ & Case-control & No & No & 5.8 (3.9 to 8.6$)$ & \\
\hline Gupta $2001^{93}$ & Lung & $\begin{array}{l}265 \text { Indian } \\
\text { individuals }\end{array}$ & Case-control & Yes & Yes & Adjusted $=4.44$ (1.2 to 16.44$)$ & OR for Male heavy smokers older than 45 years \\
\hline Lubin $1990^{94}$ & Lung & 148 Chinese men & Case-control & No & No & * & Increased risk with cumulative exposure \\
\hline Lubin $1992^{95}$ & Lung & 1438 Chinese men & Case-control & Yes & Yes & Adjusted $=1.8(0.8$ to 4.2$)$ & Did not control for Chinese long-stem pipe smoking \\
\hline Hazelton $2001^{96}$ & Lung & 12011 Chinese men & Case-control & Yes & Yes & * & Did not control for Chinese long-stem pipe smoking \\
\hline Dar $2012^{98}$ & Oesophageal & $\begin{array}{l}2365 \text { Indian } \\
\text { individuals }\end{array}$ & Case-control & Yes & Yes & Adjusted $=1.85$ (1.41 to 2.44$)$ & $\begin{array}{l}\text { Higher risk with greater intensity, duration and cumulative } \\
\text { WPS }\end{array}$ \\
\hline Malik $2010^{99}$ & Oesophageal & $\begin{array}{l}330 \text { Indian } \\
\text { individuals }\end{array}$ & Case-control & No & Yes & Adjusted=21.4 (11.6 to 39.5) & \\
\hline Nasrollahzadeh $2008^{100}$ & Oesophageal & $\begin{array}{l}871 \text { Iranian } \\
\text { individuals }\end{array}$ & Case-control & Yes & Yes & Adjusted $=1.66$ (0.65 to 4.22$)$ & OR for $>32$ WP-years smoking \\
\hline Sadjadi $2014^{101}$ & Gastric & $\begin{array}{l}928 \text { Iranian } \\
\text { individuals }\end{array}$ & Prospective cohort & Yes & Yes & Adjusted=3.4 (1.7 to 7.1$)$ & \\
\hline Karajibani $2014^{102}$ & Gastric & $\begin{array}{l}92 \text { Iranian } \\
\text { individuals }\end{array}$ & Case-control & $\dagger$ & $\dagger$ & $\dagger$ & Statistically significant association was observed \\
\hline Shakeri $2013^{103}$ & Gastric & $\begin{array}{l}922 \text { Iranian } \\
\text { individuals }\end{array}$ & Case-control & Yes & Yes & Adjusted=1.1 (0.3 to 3.3$)$ & $\begin{array}{l}\text { Also non-significant for cumulative WP use. Included a small } \\
\text { percentage of WP smokers }\end{array}$ \\
\hline Gunaid $1995^{104}$ & $\begin{array}{l}\text { Gastric and } \\
\text { Oesophageal }\end{array}$ & $\begin{array}{l}3064 \text { Yemeni } \\
\text { Individuals }\end{array}$ & Cross-sectional & Unclear & No & $\begin{array}{l}\text { Not calculated }\left(\chi^{2}=2.646 \text {, }\right. \\
P<0.05)\end{array}$ & $\begin{array}{l}\text { Number of gastric cancer cases was too small to draw } \\
\text { significant conclusions. Most WP smokers were also Qat } \\
\text { chewers, and an individual effect could not be discerned. }\end{array}$ \\
\hline Zheng $2012^{105}$ & Bladder & 1134 Egyptian men & Case-control & Yes & Yes & $\begin{array}{l}\text { Adjusted }=1.1 \text { ( } 0.7 \text { to } 1.9) \text { for } \\
\text { urothelial cancer, } \\
\text { Adjusted }=0.5(0.2 \text { to } 1.0) \text { for } \\
\text { squamous cancer }\end{array}$ & $\begin{array}{l}\text { ORs for smoking }>153 \text { Hagar-years. ORs also insignificant for } \\
\text { lesser exposures }\end{array}$ \\
\hline Bedwani $1997^{106}$ & Bladder & 308 Egyptian men & Case-control & Yes & Yes & Adjusted $=0.8(0.2$ to 4.0$)$ & \\
\hline Hosseini $2010^{107}$ & Prostate & 274 Iranian men & Case-control & Yes & Yes & $\mathrm{OR}=7.0(0.9$ to 56.9$)$ & $\begin{array}{l}\text { Adjusted OR for WP was also non-significant (but not } \\
\text { reported) }\end{array}$ \\
\hline Lo $2007^{108}$ & Pancreatic & $\begin{array}{l}388 \text { Egyptian } \\
\text { individuals }\end{array}$ & Case-control & No & Yes & Adjusted=1.6 (0.9 2.8) & $\begin{array}{l}\text { WP smoking was also not exclusive of other non-cigarette } \\
\text { forms of smoking }\end{array}$ \\
\hline Feng $2009^{109}$ & Nasopharyngeal & $\begin{array}{l}1251 \text { North African } \\
\text { individuals }\end{array}$ & Case-control & No & Yes & Adjusted $=0.49$ (0.20 to 1.43$)$ & Had small numbers of WP smokers \\
\hline
\end{tabular}

*A single OR was not reported, but there was an increased risk based on mathematical modelling, which is beyond the scope of this paper.

tOnly an abstract was available, which did not mention these variables. 
number of waterpipe smokers was too small and thus probably confounded by concurrent Qat chewing. ${ }^{104}$ Despite these two methodologically limited studies, the evidence remains supportive of an association with gastric cancer.

In contrast to the well-known association between cigarette smoking and bladder cancer, ${ }^{97}$ two case-control studies ${ }^{105} 106$ reported a weak or non-existent association between bladder cancer and WPS. The two studies controlled for cigarette smoking and other confounders.

The evidence for an association of WPS with other cancers, such as prostate, ${ }^{107}$ pancreatic $^{108}$ and nasopharyngeal carcinoma, ${ }^{7109}$ is very weak.

\section{Obstetrical and perinatal outcomes}

WPS has been associated with obstetric and perinatal complications including low birthweight (LBW). ${ }^{110-117}$ infant mortality, ${ }^{118}$ low APGAR scores, ${ }^{115}$ and pulmonary complications at birth. ${ }^{116}$ Studies were primarily retrospective or cross-sectional and were conducted in Lebanon, ${ }^{110}{ }^{114-116}$ Qatar, ${ }^{111}$ Iran, ${ }^{112} 113$ the Gaza Strip ${ }^{117}$ and Cambodia. ${ }^{118}$

Controlling for various confounders such as gestational age, parity and various obstetrical complications, one retrospective study found 2.4 (95\% CI 1.2 to 5.0 ) times greater odds of LBW $(<2500 \mathrm{~g})$ among exclusive WPS who smoked more than once a day. ${ }^{110}$ This study is limited, however, by a lack of control for important confounders such as alcohol and other substance intake. ${ }^{110}$ Another case-control study found 3.5 times greater odds (95\% CI 1.1 to 12.6 ) of LBW among WPS mothers in multivariable-adjusted analysis but, like the first study, did not control for other substance intake. ${ }^{112}$ In contrast, a retrospective study, which controlled for substance intake, found a nonsignificant association with $\mathrm{LBW}(\mathrm{OR}=1.8,95 \%$ CI 0.67 to 5.38). ${ }^{116}$ Other studies that supported an association between LBW and WPS did not account for concomitant cigarette smoking, ${ }^{111} 114115$

Passive WPS was also associated with LBW independent of cigarette and wood fuel smoke in a case-control study; however, the study had low numbers of passive WP smokers and may have suffered from recall bias. ${ }^{117}$ While a meta-analysis of three of the aforementioned studies ${ }^{110} 112116$ reported an overall 2.12 times odds of LBW in association with WPS, ${ }^{7}$ these and several additional studies ${ }^{111} 114115$ that support an association between WPS and LBW are methodologically limited with incomplete adjustment for confounders. Larger prospective cohort studies that control for important confounders are still needed.

Other adverse pregnancy outcomes were also assessed in the aforementioned and other studies. The intensity of nonexclusive WPS was inversely correlated with the APGAR scores among newborns at 5 and $10 \mathrm{~min}$ in a retrospective study that did not adjust for cigarette smoking, ${ }^{115}$ A strong association with the risk of perinatal pulmonary complications $(\mathrm{OR}=3.65$, 95\% CI 1.52 to 8.75$)$ was also demonstrated among children born to exclusive WPS mothers. ${ }^{116} \mathrm{~A}$ higher risk of infant mortality among Southern Asian WP smokers was also reported in a cross-sectional study, but the association did not reach statistical significance after adjustment for confounders. ${ }^{118}$ Furthermore, one Lebanese prospective study suggested that exclusive WPS may be associated with in vitro fertilisation failure $(\mathrm{OR}=0.41,95 \%$ CI 0.15 to 1.09 ), after controlling for maternal age, number of embryos transferred and various causes of infertility. ${ }^{119} \mathrm{An}$ Egyptian case-control study found a weak association between WPS and male factor infertility (OR $=2.5,95 \%$ CI
1.0 to 6.3 ) after controlling for confounders including cigarette smoking. ${ }^{120}$ Finally, exclusive WPS, like cigarette smoking, may influence the results of prenatal serum biomarkers and sonographical measurements used to screen for Down's syndrome as found in a Saudi cross-sectional study that did not adjust for confounders. ${ }^{121}$ Thus, most studies on the above perinatal outcomes associated with WPS were methodically limited and have not been replicated.

\section{Periodontal and oral disease}

Periodontal disease

Several cross-sectional studies conducted in Saudi Arabia assessed periodontal disease in WP smokers. Periodontal disease is associated with WPS, manifested by a lower mean age-adjusted periodontal bone height, ${ }^{122}$ larger probing depth $^{123}$ and poor gingival health as measured by plaque levels and gingival index ${ }^{124}$ This is probably not attributable to a change in the periodontal microflora, but rather to changes in the periodontal pocket depth in smokers. ${ }^{125}$ WPS is also associated with vertical periodontal bone defects, most severe among heavy WP smokers and separate from cigarette smoking effect. ${ }^{126}$ In addition, WPS was associated with three times the risk of developing dry socket after dental surgery. ${ }^{127}$ Overall, these cross-sectional studies provide supportive evidence for periodontal disease in exclusive WP smokers; however, adjustment for confounders was either absent ${ }^{127}$ or incomplete in most cases. ${ }^{123124126}$ Thus, more robust studies are still needed.

\section{Oral lesions}

Three cross-sectional studies from India, ${ }^{128}$ Saudi Arabia ${ }^{129}$ and Yemen ${ }^{130}$ assessed the association of WPS with oral lesions. WPS was associated with a greater referral rate for oral lesions suspicious for cancer after adjusting for various confounders, ${ }^{128}$ Other studies found insignificant or weak associations with suspicious oral lesions ${ }^{129}$ and leukoplakia. ${ }^{130}$ Thus, the evidence on the association of WPS and oral lesions remains inconclusive.

\section{Larynx and voice}

Two studies conducted in Lebanon demonstrated an effect of WPS on the larynx and voice. ${ }^{131} 132$ A 30 min WPS session acutely resulted in thick mucus, dilated true vocal fold blood vessels, significantly decreased vocal turbulence index and habitual pitch, and caused changes in voice parameters in a small experimental study that included 18 men and women. ${ }^{132} \mathrm{~A}$ cross-sectional study reported greater oedema, mucus and varix of the cords as well as lower vocal turbulence index and maximum phonation time in 42 long-term WP smokers compared to non-smokers; however, no confounders were taken into consideration. ${ }^{131}$ Thus, the evidence supporting an effect of WPS on the larynx and voice is limited.

\section{Osteoporosis}

Three recently published abstracts support an association between osteoporosis and WPS. A prospective cohort study of 1190 women, followed up for an average of 3.5 years, found decreased bone mass density (BMD) and an increased risk of new fractures (hazard ratio of $3.73,95 \%$ CI 1.89 to 5.16) among WP smokers compared to non-smokers, after adjusting for multiple confounders. ${ }^{133}$ Decreased BMD (lumbar spine, ${ }^{134} 135$ femur neck, total hip, total body ${ }^{135}$ ) was also associated with WPS in two other studies after adjustment for confounders including a cross-sectional study of 1880 postmenopausal women ${ }^{135}$ and a retrospective cohort study of 
60 WP smokers and 120 non-smokers. ${ }^{134}$ Of note, these data are published in abstract form.

\section{Infectious disease}

Three Egyptian cross-sectional studies found no risk for transmitting hepatitis $\mathrm{C}$ among WP users, ${ }^{136-138}$ after adjusting for confounders in two of the studies. ${ }^{136} 137$ A meta-analysis that pooled the results of these studies reached the same conclusion. ${ }^{7}$

A cluster of tuberculosis cases was reported among individuals who shared a marijuana WP; however, it was difficult to separate the effect of close contact from that of WP sharing. ${ }^{139}$ Pulmonary aspergillosis was also reported in one WP smoker with leukaemia in association with a positive fungal culture from the tobacco used. ${ }^{140}$ Despite these limited findings, the risk of infectious disease transmission through sharing WP, being a very common practice in WP cafes, certainly warrants further investigation.

\section{Other health outcomes}

WPS has been associated with a variety of other health effects. A moderate association with WPS and mental health diagnoses was observed among a large sample of US college students. ${ }^{141}$ WPS was also associated with greater BMI and risk for obesity after adjusting for cigarette smoking, number of chronic diseases, age, gender, income and marital status in a cross-sectional study of 2536 from Syria ${ }^{142}$ Further cross-sectional studies

\section{Box 1 Adverse health effects associated with waterpipe} smoking

Acute effects

- Increased heart rate

- Increased blood pressure

- Carbon monoxide intoxication

- Impaired pulmonary function (FEF25-75, PEFR)

- Decreased exercise capacity

- Larynx and voice changes

Long-term effects

- Ischaemic heart disease

- Impaired pulmonary function $\left(\mathrm{FEV}_{1}, \mathrm{FVC}_{1} \mathrm{FEV}_{1} / \mathrm{FVC}\right.$, FEF25-75, PEF, FRC, RV)

- Chronic obstructive lung disease

- Chronic bronchitis

- Emphysema

- Lung cancer

- Oesophageal cancer

- Gastric cancer

- Low birthweight

- Pulmonary problems at birth

- Periodontal disease

- Larynx and voice changes

- Lower bone density and increased fracture risk

FRC, functional residual capacity; FVC, forced vital capacity; PEF, peak expiratory flow; PEFR, peak expiratory flow rate; RV, residual volume. reported elevated urine microalbumin, ${ }^{143}$ low back pain ${ }^{144}$ and increased risk of gastroesophageal reflux disease among exclusive WP smokers ${ }^{145}$ Increased attic retractions, which predispose to cholesteatomas and possibly hearing loss, were reported in 80 ears of WP smokers. ${ }^{146}$ WPS was associated with other miscellaneous conditions in several case reports including a case of hand eczema after contact with a WP tube ${ }^{147}$ acute eosinophilic pneumonia, ${ }^{148}$ two cases of squamous cell carcinoma and lower lip keratoacanthoma ${ }^{149}$ and ulcerative colitis flare after discontinuing WPS. ${ }^{150}$ Finally, WPS was associated with lower overall health-related quality of life in a cross-sectional study of 1675 , after adjusting for cigarette smoking and other variables. ${ }^{151}$ Overall, the findings of these single reports require further confirmation.

\section{CONCLUSIONS}

This review outlined the spectrum of acute and long-term health effects of WPS on multiple organ systems. Health effects and outcomes associated with WPS are summarised in box 1. The greatest impact demonstrated to date is on the cardiovascular and respiratory systems, most seriously leading to CAD and COPD encompassing chronic bronchitis and emphysema.

Although these studies provide evidence that WPS, like cigarette smoking, leads to impaired cardiovascular and PF and several adverse health outcomes, methodological limitations are noted in most studies. A number of studies did not control for concurrent cigarette or other tobacco smoking. Most are cross-sectional and some are exclusively hospitalbased with incomplete adjustments for potential confounders. Other limitations, as found in a meta-analysis, include the heterogeneity and under-reporting of methods used to measure variables, poor sampling methods, limited assessment of gender and age as confounders, absence of blinding, incompleteness of data and absence of a standard exposure assessment tool. ${ }^{72}$ Furthermore, most studies failed to report the specific type of tobacco used. The long-term effects of smoking traditional (non-flavoured) tobacco versus smoking flavoured (moassal) may be different and needs to be assessed, particularly with the difference in the profile of smokers of each tobacco type.

Thus, large, well-designed, prospective,longitudinal, community-based studies are needed to better assess the longterm health effects of WPS. In addition, future studies must account for the state of knowledge on the ingredients and emissions of flavoured tobacco products, puffing parameters and duration of smoking. Finally, the effect of passive WPS is another area that has been minimally studied and warrants further investigation. Despite all the stated limitations, there is enough evidence to suggest that WPS has harmful health effects and this knowledge should be used to educate the public to dispel the notions of safety of use, and design public health interventions and research work to fill in the gaps in knowledge on the health effects of WPS. This knowledge should guide regulators ${ }^{152}$ on appropriate measures to curb this epidemic by implementing health warning labels on packages and in public places of use, banning of misleading information on contents and emissions, and limiting access to youth and minors. 


\section{What this paper adds}

What is already known on this subject

- Waterpipe smoking is known to expose participants to a variety of potentially harmful toxicants.

- Numerous studies have been published assessing the clinical effects of waterpipe smoking on human health with emphasis on the cardiovascular and respiratory systems. The literature suggests that waterpipe smoking is also harmful to other organ systems.

What important gaps in knowledge exist on this topic

- The extent to which waterpipe smoking harms human health is not well known.

- Most available studies are methodologically limited and have not been extensively reviewed. Thus, an assessment of the current literature is needed to support or refute the suspected harmful effects of waterpipe smoking and suggest what gaps need to be addressed in future work.

\section{What this paper adds}

- This narrative review synthesises the published literature on the extent of the health effects of waterpipe smoking on multiple organ systems.

- This study offers a comprehensive review of the acute and long-term health effects of waterpipe smoking on multiple organs with emphasis on the salient ones.

- Despite the limitations of some published studies, there is supportive evidence of the harmful effects of waterpipe smoking that lead to morbidity and mortality in humans.

- This study underscores the need to use this knowledge to educate the public, to dispel misconceptions about safety, and to urge the regulators to undertake effective control measures.

Contributors The idea for this manuscript arose in consultation with the scientific committee for the Second International Conference on Waterpipe Smoking Research (GSZ is a member of this committee). The literature search was performed by ZME, with GSZ overseeing the search. All authors contributed to the writing and editing of this article. GSZ is the guarantor.

\section{Competing interests None.}

Provenance and peer review Commissioned; externally peer reviewed.

Open Access This is an Open Access article distributed in accordance with the Creative Commons Attribution Non Commercial (CC BY-NC 4.0) license, which permits others to distribute, remix, adapt, build upon this work non-commercially, and license their derivative works on different terms, provided the original work is properly cited and the use is non-commercial. See: http://creativecommons.org/ licenses/by-nc/4.0/

\section{REFERENCES}

1 Gatrad R, Gatrad A, Sheikh A. Hookah smoking. BMJ 2007;335:20.

2 AkI EA, Gunukula SK, Aleem S, et al. The prevalence of waterpipe tobacco smoking among the general and specific populations: a systematic review. $B M C$ Public Health 2011;11:244.

3 Maziak W, Nakkash R, Bahelah R, et al. Tobacco in the Arab world: old and new epidemics amidst policy paralysis. Health Policy Plan 2014;29:784-94.

4 Maziak W, Ben Taleb Z, Bahelah R, et al. The global epidemiology of waterpipe smoking. Tob Control 2015;24:13-12.

5 Daher N, Saleh R, Jaroudi E, et al. Comparison of carcinogen, carbon monoxide, and ultrafine particle emissions from narghile waterpipe and cigarette smoking: sidestream smoke measurements and assessment of second-hand smoke emission factors. Atmos Environ (1994) 2010;44:8-14.

6 Shihadeh A, Saleh R. Polycyclic aromatic hydrocarbons, carbon monoxide, "tar", and nicotine in the mainstream smoke aerosol of the narghile water pipe. Food Chem Toxicol 2005;43:655-61.

7 Akl EA, Gaddam S, Gunukula SK, et al. The effects of waterpipe tobacco smoking on health outcomes: a systematic review. Int J Epidemiol 2010;39:834-57.
8 Shafagoj YA, Mohammed FI. Levels of maximum end-expiratory carbon monoxide and certain cardiovascular parameters following hubble-bubble smoking. Saudi Med J 2002;23:953-8.

9 Shaikh RB, Vijayaraghavan N, Sulaiman AS, et al. The acute effects of waterpipe smoking on the cardiovascular and respiratory systems. J Prev Med Hyg 2008;49:101-7.

10 Hakim F, Hellou E, Goldbart A, et al. The acute effects of water-pipe smoking on the cardiorespiratory system. Chest 2011;139:775-81.

11 Kadhum M, Jaffery A, Haq A, et al. Measuring the acute cardiovascular effects of shisha smoking: a cross-sectional study. JRSM Open 2014;5:2054270414531127.

12 Al-Kubati M, Al-Kubati AS, al'Absi M, et al. The short-term effect of water-pipe smoking on the baroreflex control of heart rate in normotensives. Auton Neurosci 2006;126-127:146-9.

13 Hawari Fl, Obeidat NA, Ayub H, et al. The acute effects of waterpipe smoking on lung function and exercise capacity in a pilot study of healthy participants. Inhal Toxicol 2013;25:492-7.

14 Cobb CO, Sahmarani K, Eissenberg T, et al. Acute toxicant exposure and cardiac autonomic dysfunction from smoking a single narghile waterpipe with tobacco and with a "healthy" tobacco-free alternative. Toxicol Lett 2012;215:70-5.

15 Shishani K, Howell D, McPherson S, et al. Young adult waterpipe smokers: smoking behaviors and associated subjective and physiological effects. Addict Behav 2014;39:1113-19.

16 Bentur L, Hellou E, Goldbart A, et al. Laboratory and clinical acute effects of active and passive indoor group water-pipe (narghile) smoking. Chest 2014;145: 803-9.

17 Eissenberg T, Shihadeh A. Waterpipe tobacco and cigarette smoking: direct comparison of toxicant exposure. Am J Prev Med 2009;37:518-23.

18 Blank MD, Cobb CO, Kilgalen B, et al. Acute effects of waterpipe tobacco smoking: a double-blind, placebo-control study. Drug Alcohol Depend 2011;116:102-9.

19 Al-Osaimi A, Obaid O, Al-Asfour Y, et al. The acute effect of shisha smoking on oxygen saturation level and heart rate. Med Princ Pract 2012;21:588

20 Alomari MA, Khabour OF, Alzoubi KH, et al. Central and peripheral cardiovascular changes immediately after waterpipe smoking. Inhal Toxicol 2014; 26:579-87

21 Layoun N, Saleh N, Barbour B, et al. Waterpipe effects on pulmonary function and cardiovascular indices: a comparison to cigarette smoking in real life situation. Inhal Toxicol 2014:26:620-7.

22 Neergaard J, Singh P, Job J, et al. Waterpipe smoking and nicotine exposure: a review of the current evidence. Nicotine Tob Res 2007:9:987-94.

23 Cryer PE, Haymond MW, Santiago JV, et al. Norepinephrine and epinephrine release and adrenergic mediation of smoking-associated hemodynamic and metabolic events. N Engl J Med 1976;295:573-7.

24 Jabbour S, El-Roueiheb Z, Sibai AM. Narghile (water-pipe) smoking and incident coronary heart disease: a case-control study. Ann Epidemiol 2003;13:570.

25 Islami F, Pourshams A, Vedanthan R, et al. Smoking water-pipe, chewing nass and prevalence of heart disease: a cross-sectional analysis of baseline data from the Golestan Cohort Study, Iran. Heart 2013;99:272-8.

26 Wu F, Chen Y, Parvez F, et al. A prospective study of tobacco smoking and mortality in Bangladesh. PLOS ONE 2013;8:e58516.

27 Mateen FJ, Carone M, Alam N, et al. A population-based case-control study of 1250 stroke deaths in rural Bangladesh. Eur I Neurol 2012;19:999-1006.

28 Sibai AM, Tohme RA, Almedawar MM, et al. Lifetime cumulative exposure to waterpipe smoking is associated with coronary artery disease. Atherosclerosis 2014;234:454-60.

29 Al Suwaidi J, Al Habib K, Singh R, et al. Tobacco modalities used and outcome in patients with acute coronary syndrome: an observational report. Postgrad Med J 2012:88:566-74.

30 Selim GM, Fouad H, Ezzat S. Impact of shisha smoking on the extent of coronary artery disease in patients referred for coronary angiography. Anadolu Kardiyol Derg 2013;13:647-54.

31 Al-Safi SA, Ayoub NM, Albalas MbA, et al. Does shisha smoking affect blood pressure and heart rate? J Public Health 2009;17:121-6.

32 Selim GM, Elia RZ, El Bohey AS, et al. Effect of shisha vs. cigarette smoking on endothelial function by brachial artery duplex ultrasonography: an observational study. Anadolu Kardiyol Derg 2013;13:759-65.

33 Wolfram RM, Chehne F, Oguogho A, et al. Narghile (water pipe) smoking influences platelet function and (iso-)eicosanoids. Life Sci 2003;74:47-53.

34 Ambrose JA, Barua RS. The pathophysiology of cigarette smoking and cardiovascular disease: an update. J Am Coll Cardiol 2004;43:1731-7.

35 Theron A, Schultz C, Ker JA, et al. Carboxyhaemoglobin levels in water-pipe and cigarette smokers. S Afr Med J 2010;100:122-4.

36 Zahran F, Yousef AA, Baig MH. A study of carboxyhaemoglobin levels of cigarette and sheesha smokers in Saudi Arabia. Am J Public Health 1982;72:722-4.

37 Zahran FM, Ardawi MS, Al-Fayez SF. Carboxyhemoglobin concentrations in smokers of sheesha and cigarettes in Saudi Arabia. BMJ (Clin Res Ed) 1985;291:1768-70. 
38 Lopez JR, Somsamouth K, Mounivong B, et al. Carbon monoxide levels in water pipe smokers in rural Laos PDR. Tob Control 2012;21:517-18.

39 El-Nachef WN, Hammond SK. Exhaled carbon monoxide with waterpipe use in US students. JAMA 2008:299:36-8.

40 Singh S, Soumya M, Saini $A$, et al. Breath carbon monoxide levels in different forms of smoking. Indian J Chest Dis Allied Sci 2011;53:25-8.

41 Akhter S, Warraich UA, Rizvi N, et al. Comparison of end tidal carbon monoxide (eCO) levels in shisha (water pipe) and cigarette smokers. Tob Induc Dis 2014;12:10.

42 Yalcin FK, Er M, Senturk A, et al. Respiratory functions, levels of carbonmonoxide and oxidative stress in hookah smokers [abstract]. Chest 2014;145 (3_MeetingAbstracts):431C.

43 Martinasek MP, Ward KD, Calvanese AV. Change in carbon monoxide exposure among waterpipe bar patrons. Nicotine Tob Res 2014;16:1014-19.

44 Barnett TE, Curbow BA, Soule EK, et al. Carbon monoxide levels among patrons of hookah cafes. Am J Prev Med 2011;40:324-8.

45 Zeidan RK, Rachidi S, Awada S, et al. Carbon monoxide and respiratory symptoms in young adult passive smokers: a pilot study comparing waterpipe to cigarette. Int J Occup Med Environ Health 2014:27:571-82.

46 Ozkan S, Ozturk T, Ozmen Y, et al. Syncope associated with carbon monoxide poisoning due to narghile smoking. Case Rep Emerg Med 2013;2013:796857.

47 Bens BW, ter Maaten JC, Ligtenberg JJ. [Carbon monoxide poisoning after smoking from a water pipe]. Ned Tijdschr Geneeskd 2013;157:A6201.

48 Kesner KL, Ramaiah VK, Hemmer LB, et al. Anesthesia implications of waterpipe use. J Clin Anesth 2012;24:137-40.

49 La Fauci G, Weiser G, Steiner IP, et al. Carbon monoxide poisoning in narghile (water pipe) tobacco smokers. CJEM 2012;14:57-9.

50 Clarke SF, Stephens C, Farhan M, et al. Multiple patients with carbon monoxide toxicity from water-pipe smoking. Prehosp Disaster Med 2012;27:612-14.

51 Ashurst JV, Urquhart M, Cook MD. Carbon monoxide poisoning secondary to hookah smoking. J Am Osteopath Assoc 2012;112:686-8.

52 Cavus UY, Rehber ZH, Ozeke 0 , et al. Carbon monoxide poisoning associated with narghile use. Emerg Med J 2010;27:406.

53 Lim BL, Lim GH, Seow E. Case of carbon monoxide poisoning after smoking shisha. Int J Emerg Med 2009;2:121-2.

54 Karaca Y, Eryigit U, Aksut N, et al. Syncope associated with water pipe smoking. BMJ Case Rep 2013;2013:pii:bcr2013009526.

55 Misek R, Patte C. Carbon monoxide toxicity after lighting coals at a hookah bar. J Med Toxicol 2014;10:295-8.

56 Arziman I, Acar YA, Yildirim AO, et al. Five cases of carbon monoxide poisoning due to narghile (shisha). Hong Kong J Emerg Med 2011;18:254-7.

57 Abbas NT, Khan DA, Begum J. Carboxyhemoglobin levels among hookah smokers, cigarette smokers and non-smokers: a crosssectional descriptive study [abstract]. Clin Chem Lab Med 2014;52(Suppl 1):S790.

58 Tadmor T, Mishchenko E, Polliack A, et al. Hookah (narghile) smoking: a new emerging cause of secondary polycythemia. Am J Hematol 2011;86:719-20.

59 Bonadies N, Tichelli A, Rovó A. When water does not clear the smut from the smoke. BMJ Case Rep 2013;2013:pii:bcr2013200665.

60 Salameh P, Khayat G, Waked M. Validation of the respiratory toxics exposure score (RTES) for chronic obstructive pulmonary disease screening. Int I Occup Med Environ Health 2011;24:339-47.

61 Boskabady MH, Farhang L, Mahmodinia M, et al. Comparison of pulmonary function and respiratory symptoms in water pipe and cigarette smokers. Respirology 2012;17:950-6.

62 Ben Saad H, Khemis M, Bougmiza I, et al. Spirometric profile of narghile smokers. Rev Mal Respir 2011;28:e39-51.

63 Ben Saad H, Khemiss M, Nhari S, et al. Pulmonary functions of narghile smokers compared to cigarette smokers: a case-control study. Libyan J Med 2013;8:22650.

64 Al Mutairi SS, Shihab-Eldeen AA, Mojiminiyi OA, et al. Comparative analysis of the effects of hubble-bubble (Sheesha) and cigarette smoking on respiratory and metabolic parameters in hubble-bubble and cigarette smokers. Respirology 2006;11:449-55.

65 Aydin A, Kiter G, Durak $\mathrm{H}$, et al. Water-pipe smoking effects on pulmonary permeability using technetium-99m DTPA inhalation scintigraphy. Ann Nucl Med 2004;18:285-9.

66 Kiter G, Uçan ES, Ceylan E, et al. Water-pipe smoking and pulmonary functions. Respir Med 2000;94:891-4.

67 Mohammad Y, Shaaban R, Al-Zahab BA, et al. Impact of active and passive smoking as risk factors for asthma and COPD in women presenting to primary care in Syria: first report by the WHO-GARD survey group. Int $J$ Chron Obstruct Pulmon Dis 2013;8:473-82.

68 Mohammad Y, Kakah M. Chronic respiratory effect of narguileh smoking compared with cigarette smoking in women from the East Mediterranean region. Int I Chron Obstruct Pulmon Dis 2008;3:405-14.

69 She J, Yang P, Wang Y, et al. Chinese waterpipe smoking and the risk of chronic obstructive pulmonary disease. Chest 2014;146:924-31.

70 Al-Fayez SF, Salleh M, Ardawi M, et al. Effects of sheesha and cigarette smoking on pulmonary function of Saudi males and females. Trop Geogr Med 1988;40:115-23.
71 Boskabady MH, Farhang L, Mahmoodinia M, et al. Prevalence of water pipe smoking in the city of Mashhad (North East of Iran) and its effect on respiratory symptoms and pulmonary function tests. Lung India 2014;31: 237-43.

72 Raad D, Gaddam S, Schunemann HJ, et al. Effects of water-pipe smoking on lung function: a systematic review and meta-analysis. Chest 2011;139:764-74.

73 Ben Saad H, Babba M, Boukamcha R, et al. Investigation of exclusive narghile smokers: deficiency and incapacity measured by spirometry and 6-Minute Walk Test. Respir Care 2014;59:1696-709.

74 Global Strategy for the Diagnosis, Management, and Prevention of COPD, Global Initiative for Chronic Obstructive Lung Disease (GOLD) 2014. http://www.goldcopd. org/

75 Waked M, Khayat G, Salameh P. Chronic obstructive pulmonary disease prevalence in Lebanon: a cross-sectional descriptive study. Clin Epidemiol 2011:3:315-23.

76 Tageldin MA, Nafti S, Khan JA, et al. Distribution of COPD-related symptoms in the Middle East and North Africa: results of the BREATHE study. Respir Med 2012;106(Suppl 2):S25-32.

77 Al Zaabi A, Asad F, Abdou J, et al. Prevalence of COPD in Abu Dhabi, United Arab Emirates. Respir Med 2011;105:566-70.

78 Waked M, Salameh P, Aoun Z. Water-pipe (narguile) smokers in Lebanon: a pilot study. East Mediterr Health J 2009;15:432-42.

79 Salameh P, Waked M, Khoury F, et al. Waterpipe smoking and dependence are associated with chronic bronchitis: a case-control study in Lebanon. East Mediterr Health J 2012;18:996-1004.

80 Parasuramalu BG, Huliraj N, Rudraprasad BM, et al. Prevalence of bronchial asthma and its association with smoking habits among adult population in rural area. Indian J Public Health 2010;54:165-8.

81 Nemmar A, Yuvaraju P, Beegam S, et al. Cardiovascular effects of nose-only water-pipe smoking exposure in mice. Am J Physiol Heart Circ Physiol 2013;305: H740-6.

82 Khabour OF, Alzoubi KH, Bani-Ahmad M, et al. Acute exposure to waterpipe tobacco smoke induces changes in the oxidative and inflammatory markers in mouse lung. Inhal Toxicol 2012;24:667-75.

83 Miri-Moghaddam E, Mirzaei R, Arab MR, et al. The effects of waterpipe smoking on hematological parameters in rats. Int I Hematol Oncol Stem Cell Res 2014;8:37-43.

84 Mirsadraee M, Khakzad MR, Ahmadzadeh M, et al. Acute effect of water pipe smoke on sensitized animals. Tanaffos 2010;9:39-47.

85 Kaddah S, Rashed L, Obaia E, et al. A preliminary study: matrix metalloproteinase expression as an indicator of the hazards of shisha (narghila) smoking. Arch Med Sci 2009:5:570-6.

86 Alsatari ES, Azab M, Khabour OF, et al. Assessment of DNA damage using chromosomal aberrations assay in lymphocytes of waterpipe smokers. Int J Occup Med Environ Health 2012;25:218-24.

87 Khabour OF, Alsatari ES, Azab M, et al. Assessment of genotoxicity of waterpipe and cigarette smoking in lymphocytes using the sister-chromatid exchange assay: a comparative study. Environ Mol Mutagen 2011;52:224-8.

88 El-Setouhy M, Loffredo CA, Radwan G, et al. Genotoxic effects of waterpipe smoking on the buccal mucosa cells. Mutat Res 2008;655: $36-40$.

89 Yadav JS, Thakur S. Genetic risk assessment in hookah smokers. Cytobios 2000;101:101-13.

90 Seifi S, Feizi F, Mehdizadeh M, et al. Evaluation of cytological alterations of oral mucosa in smokers and waterpipe users. Cell I 2014;15:302-9.

91 Aoun J, Saleh N, Waked M, et al. Lung cancer correlates in Lebanese adults: a pilot case-control study. J Epidemiol Glob Health 2013;3:235-44.

92 Koul PA, Hajni MR, Sheikh MA, et al. Hookah smoking and lung cancer in the Kashmir valley of the Indian subcontinent. Asian Pac J Cancer Prev 2011;12:519-24.

93 Gupta D, Boffetta P, Gaborieau V, et al. Risk factors of lung cancer in Chandigarh, India. Indian J Med Res 2001;113:142-50.

94 Lubin JH, Qiao YL, Taylor PR, et al. Quantitative evaluation of the radon and lung cancer association in a case control study of Chinese tin miners. Cancer Res 1990:50:174-80.

95 Lubin JH, Li JY, Xuan XZ, et al. Risk of lung cancer among cigarette and pipe smokers in southern China. Int I Cancer 1992:51:390-5.

96 Hazelton WD, Luebeck EG, Heidenreich WF, et al. Analysis of a historical cohort of Chinese tin miners with arsenic, radon, cigarette smoke, and pipe smoke exposures using the biologically based two-stage clonal expansion model. Radiat Res 2001;156:78-94.

97 National Center for Chronic Disease Prevention and Health Promotion, Office on Smoking and Health. Highlights: Scientific Review of Findings Regarding Cancer. 2010. http://www.cdc.gov/tobacco/data_statistics/by_topic/health_effects/index.htm

98 Dar NA, Bhat GA, Shah IA, et al. Hookah smoking, nass chewing, and oesophageal squamous cell carcinoma in Kashmir, India. Br J Cancer 2012;107:1618-23. 
99 Malik MA, Upadhyay R, Mittal RD, et al. Association of xenobiotic metabolizing enzymes genetic polymorphisms with esophageal cancer in Kashmir Valley and influence of environmental factors. Nutr Cancer 2010;62:734-42.

100 Nasrollahzadeh D, Kamangar F, Aghcheli K, et al. Opium, tobacco, and alcohol use in relation to oesophageal squamous cell carcinoma in a high-risk area of Iran. Br J Cancer 2008;98:1857-63.

101 Sadjadi A, Derakhshan MH, Yazdanbod A, et al. Neglected role of hookah and opium in gastric carcinogenesis: a cohort study on risk factors and attributable fractions. Int J Cancer 2014;134:181-8.

102 Karajibani M, Montazerifar F, Dashipour A, et al. Nutritional risk factors in the gastric cancer patients attending in Imam Ali Hospital, Zahedan, Iran. RMJ 2014;39:19-24.

103 Shakeri R, Malekzadeh R, Etemadi $A$, et al. Opium: an emerging risk factor for gastric adenocarcinoma. Int J Cancer 2013;133:455-61.

104 Gunaid AA, Sumairi AA, Shidrawi RG, et al. Oesophageal and gastric carcinoma in the Republic of Yemen. Br J Cancer 1995;71:409-10.

105 Zheng YL, Amr S, Saleh DA, et al. Urinary bladder cancer risk factors in Egypt: a multicenter case-control study. Cancer Epidemiol Biomarkers Prev 2012;21:537-46.

106 Bedwani R, el-Khwsky F, Renganathan $E$, et al. Epidemiology of bladder cancer in Alexandria, Egypt: tobacco smoking. Int J Cancer 1997;73:64-7.

107 Hosseini M, SeyedAlinaghi S, Mahmoudi M, et al. A case-control study of risk factors for prostate cancer in Iran. Acta Med Iran 2010;48:61-6.

108 Lo AC, Soliman AS, El-Ghawalby N, et al. Lifestyle, occupational, and reproductive factors in relation to pancreatic cancer risk. Pancreas 2007;35:120-9.

109 Feng BJ, Khyatti M, Ben-Ayoub W, et al. Cannabis, tobacco and domestic fumes intake are associated with nasopharyngeal carcinoma in North Africa. Br J Cancer 2009;101:1207-12.

110 Tamim H, Yunis KA, Chemaitelly $H$, et al. National Collaborative Perinatal Neonatal Network Beirut Lb. Effect of narghile and cigarette smoking on newborn birthweight. BJOG 2008;115:91-7.

111 Bener A, Salameh KM, Yousafzai MT, et al. Pattern of maternal complications and low birth weight: associated risk factors among highly endogamous women. ISRN Obstet Gynecol 2012;2012:540495.

112 Aghamolaei T, Eftekhar H, Zare S. Risk factors associated with intrauterine growth retardation (IUGR) in Bandar Abbas. J Med Sci 2007;7:665-9.

113 Ranjbar $\mathrm{H}$, Kohan $\mathrm{M}$, Abbaszadeh $\mathrm{A}$, et al. The survey of prevalence of violence against mother and substance abuse and their relation with Low Birth Weight (LBW) and preterm birth in Kerman in 2008. Iran J Obstet Gynecol Infertility 2008; $14: 6$

114 Bachir R, Chaaya M. Maternal smoking: determinants and associated morbidity in two areas in Lebanon. Matern Child Health J 2008:12:298-307.

115 Rachidi S, Awada S, Al-Hajje A, et al. Risky substance exposure during pregnancy: a pilot study from Lebanese mothers. Drug Healthc Patient Saf 2013;5:123-31.

116 Nuwayhid IA, Yamout B, Azar G, et al. Narghile (hubble-bubble) smoking, low birth weight, and other pregnancy outcomes. Am J Epidemiol 1998;148:375-83.

117 Abusalah A, Gavana M, Haidich AB, et al. Low birth weight and prenatal exposure to indoor pollution from tobacco smoke and wood fuel smoke: a matched case-control study in Gaza Strip. Matern Child Health J 2012;16:1718-27.

118 Singh PN, Eng C, Yel D, et al. Maternal use of cigarettes, pipes, and smokeless tobacco associated with higher infant mortality rates in Cambodia. Asia Pac J Public Health 2013;25(5 Suppl):64S-74.

119 Hannoun A, Nassar AH, Usta IM, et al. Effect of female nargile smoking on in vitro fertilization outcome. Eur J Obstet Gynecol Reprod Biol 2010;150:171-4.

120 Inhorn MC, Buss KA. Ethnography, epidemiology and infertility in Egypt. Soc SCi Med 1994;39:671-86.

121 Ardawi MS, Nasrat HA, Rouzi AA, et al. The effect of cigarette or sheesha smoking on first-trimester markers of Down syndrome. BJOG 2007;114:1397-401.

122 Natto S, Baljoon M, Bergström J. Tobacco smoking and periodontal bone height in a Saudi Arabian population. J Clin Periodontol 2005;32:1000-6.

123 Natto S, Baljoon M, Bergström J. Tobacco smoking and periodontal health in a Saudi Arabian population. J Periodontol 2005;76:1919-26.

124 Natto S, Baljoon M, Abanmy A, et al. Tobacco smoking and gingival health in a Saudi Arabian population. Oral Health Prev Dent 2004;2:351-7.

125 Natto S, Baljoon M, Dahlén G, et al. Tobacco smoking and periodontal microflora in a Saudi Arabian population. J Clin Periodontol 2005;32:549-55.

126 Baljoon M, Natto S, Abanmy A, et al. Smoking and vertical bone defects in a Saudi Arabian population. Oral Health Prev Dent 2005;3:173-82.

127 Al-Belasy FA. The relationship of "shisha" (water pipe) smoking to postextraction dry socket. J Oral Maxillofac Surg 2004;62:10-14.
128 Dangi J, Kinnunen TH, Zavras Al. Challenges in global improvement of oral cancer outcomes: findings from rural Northern India. Tob Induc Dis 2012;10:5.

129 Al-Attas SA, Ibrahim SS, Amer HA, et al. Prevalence of potentially malignant oral mucosal lesions among tobacco users in Jeddah, Saudi Arabia. Asian Pac J Cancer Prev 2014;15:757-62.

130 Schmidt-Westhausen AM, Al Sanabani J, Al-Sharabi AK. Prevalence of oral white lesions due to qat chewing among women in Yemen. Oral Dis 2014;20:675-81.

131 Hamdan AL, Sibai A, Oubari D, et al. Laryngeal findings and acoustic changes in hubble-bubble smokers. Eur Arch Otorhinolaryngol 2010;267:1587-92.

132 Hamdan AL, Sibai A, Mahfoud L, et al. Short term effect of hubble-bubble smoking on voice. J Laryngol Otol 2011;125:486-91.

133 Ardawi MS, Bahksh T, Sibiani A, et al. Shisha (hubbly bubbly) smoking is a strong risk factor for fractures in postmenopausal women: the ceor study [abstract]. Osteoporos Int 2013;24(Suppl 1):S217.

134 Gheidar F, Jamshidi R, Najafyarandi A, et al. The correlation between hubble bubble smoking and bone mineral density of potmenopausal women referred to BMD clinic of Namazi hospital Shiraz, Iran, 2004 [abstract]. Osteoporos Int 2010;21(Suppl 5):S736-7.

135 Ardawi MS, Akbar D, Alshaikh A, et al. Shisha (hubbly bubbly) smoking is associated with a significant decrease in BMD among postmenopausal women [abstract]. Osteoporos Int 2013;24(Suppl 1):S213.

136 Medhat A, Shehata M, Magder LS, et al. Hepatitis c in a community in Upper Egypt: risk factors for infection. Am J Trop Med Hyg 2002;66:633-8.

137 Habib M, Mohamed MK, Abdel-Aziz F, et al. Hepatitis C virus infection in a community in the Nile Delta: risk factors for seropositivity. Hepatology 2001;33:248-53.

138 el-Sadawy M, Ragab $\mathrm{H}$, el-Toukhy $\mathrm{H}$, et al. Hepatitis C virus infection at Sharkia Governorate, Egypt: seroprevalence and associated risk factors. J Egypt Soc Parasitol 2004;34(1 Suppl):367-84.

139 Munckhof WJ, Konstantinos A, Wamsley M, et al. A cluster of tuberculosis associated with use of a marijuana water pipe. Int I Tuberc Lung Dis 2003;7:860-5.

140 Szyper-Kravitz M, Lang R, Manor Y, et al. Early invasive pulmonary aspergillosis in a leukemia patient linked to aspergillus contaminated marijuana smoking. Leuk Lymphoma 2001;42:1433-7.

141 Primack BA, Land SR, Fan J, et al. Associations of mental health problems with waterpipe tobacco and cigarette smoking among college students. Subst Use Misuse 2013:48:211-19.

142 Ward KD, Ahn S, Mzayek F, et al. The relationship between waterpipe smoking and body weight: population-based findings from Syria. Nicotine Tob Res 2015; 17:34-40.

143 Ishtiaque I, Shafique K, Ul-Haq Z, et al. Water-pipe smoking and albuminuria: new dog with old tricks. PLOS ONE 2014;9:e85652.

144 Bener A, Dafeeah EE, Alnaqbi K. Prevalence and correlates of low back pain in primary care: what are the contributing factors in a rapidly developing country. Asian Spine J 2014;8:227-36.

145 Islami F, Nasseri-Moghaddam S, Pourshams A, et al. Determinants of gastroesophageal reflux disease, including hookah smoking and opium use- a cross-sectional analysis of 50,000 individuals. PLOS ONE 2014;9:e89256.

146 Effat KG. Otoscopic appearances and tympanometric changes in narghile smokers. J Laryngol Otol 2004;118:818-21.

147 Onder M, Oztas M, Arnavut O. Nargile (Hubble-Bubble) smoking-induced hand eczema. Int J Dermatol 2002;41:771-2.

148 Raj V, Berman A. Acute eosinophilic pneumonia after use of a hookah (water pipe) causing severe hypoxemia requiring ECMO [abstract]. Chest 2014;144 (4_MeetingAbstracts):916A

149 El-Hakim IE, Uthman MA. Squamous cell carcinoma and keratoacanthoma of the lower lip associated with "Goza" and "Shisha" smoking. Int J Dermatol 1999;38:108-10.

150 Borum M, Ginsberg A, Jencks D. The importance of cultural sensitivity and awareness management of inflammatory bowel disease: a case of smoking the hookah and ulcerative colitis flare [abstract]. Inflamm Bowel Dis 2011;17(Suppl 1):S41.

151 Tavafian SS, Aghamolaei T, Zare S. Water pipe smoking and health-related quality of life: a population-based study. Arch Iran Med 2009;12:232-7.

152 World Health Organization. TobReg advisory note: waterpipe tobacco smoking: health effects, research needs and recommended actions by regulators. Geneva, Switzerland, 2005. http://www.who.int/tobacco/global_interaction/tobreg/ Waterpipe\%20recommendation_Final.pdf?ua=1 